\title{
Fluoride does not induce DNA breakage in Chinese hamster ovary cells in vitro
}

\section{Flúor não induz danos ao DNA em células de ovário de hamster chinês in vitro}

\author{
Daniel Araki Ribeiro* \\ Clarissa Scolastici* \\ Mariângela Esther Alencar Marques** \\ Daisy Maria Fávero Salvadori***
}

\begin{abstract}
Fluoride has been widely used in dentistry because it is a specific and effective caries prophylactic agent. However, excess fluoride may represent a hazard to human health, especially by causing injury to genetic material. Genotoxicity tests represent an important part of cancer research to assess the risk of potential carcinogens. In the current study, the potential DNA damage associated with exposure to fluoride was assessed by the single cell gel (comet) assay in vitro. Chinese hamster ovary cells were exposed to sodium fluoride (NaF) at final concentration ranging from 7 to $100 \mu \mathrm{g} / \mathrm{ml}$ for $3 \mathrm{~h}$, at $37^{\circ} \mathrm{C}$. The results pointed out that $\mathrm{NaF}$ in all concentrations tested did not contribute to DNA damage as depicted by the mean tail moment and tail intensity. These findings are clinically important since they represent an important contribution to a correct evaluation of the potential health risk associated with the exposure to dental agents.
\end{abstract}

DESCRIPTORS: Sodium fluoride; Comet assay; Mutagenicity tests.

\begin{abstract}
RESUMO: O flúor tem sido amplamente usado na Odontologia, pois é um agente profilático efetivo e específico contra a cárie dentária. Entretanto, o flúor em excesso pode representar perigos à saúde humana, especialmente por causar agressão ao material genético. Testes de genotoxicidade representam uma importante parte da pesquisa do câncer para a avaliação de risco de possiveis carcinógenos. Neste presente estudo, danos ao DNA associados à exposição ao flúor foram avaliados pelo teste de células individualizadas em gel de agarose (teste do cometa) in vitro. Células de ovário de hamster chinês foram expostas ao fluoreto de sódio (NaF) nas concentrações finais de 7 a $100 \mu \mathrm{g} / \mathrm{ml}$, durante $3 \mathrm{~h}$, a $37^{\circ} \mathrm{C}$. Os resultados mostraram que o NaF não contribuiu para os danos no DNA em todas as concentrações testadas, conforme demonstrado pelas médias do momento da cauda e da intensidade da cauda dos cometas. Esses achados são clinicamente importantes, uma vez que representam uma importante contribuição para a correta avaliação do potencial risco à saúde associada à exposição aos agentes odontológicos.
\end{abstract}

DESCRITORES: Fluoreto de sódio; Ensaio em cometa; Testes de mutagenicidade.

\section{INTRODUCTION}

Fluoride intake in low concentrations during tooth development results in formation of more resistant to caries dental enamel ${ }^{4}$. It was established that a concentration of $0.7 \mathrm{ppm}$ fluoride reduces caries by $40-49 \%$ in primary teeth and $50-$ $59 \%$ in permanent teeth, with no clinical appearance of adverse effects ${ }^{26}$. However, some human populations are exposed to high doses of fluoride, mainly in developing countries. Studies focusing on possible genotoxic effect of excess fluoride are contradictory and inconclusive ${ }^{16}$. According to some authors, fluoride does not induce DNA dam- age $^{10,13,18,22}$. However, some authors have observed the genotoxic potential of fluoride in Drosophila melanogaster ${ }^{7}$ as well as synergistic and antagonist effect with known genotoxins ${ }^{20}$.

Over the past decade, the single cell gel (comet) assay in alkaline version has been a rapid, simple and reliable biochemical technique for evaluating DNA damage in mammalian cells ${ }^{23}$. The basic principle of the single cell gel (comet) assay is the migration of DNA in an agarose matrix under electrophoretic conditions. When viewed under a microscope, a cell has the appearance of a comet,

\footnotetext{
*Graduate Students; **Head Professor; ***PhD, Researcher of Center for Genotoxins and Carcinogens Evaluation (TOXICAN) Department of Pathology, School of Medicine of Botucatu, São Paulo State University.
} 
Ribeiro DA, Scolastici C, Marques MEA, Salvadori DMF. Fluoride does not induce DNA breakage in Chinese hamster ovary cells in vitro. Braz Oral Res 2004;18(3):192-6.

with head (the nuclear region) and tail containing DNA fragments or strands migrating in the direction of the anode. In particular, this assay seems important for the investigation of suspected genotoxins in vitro ${ }^{21}$ and in vivo ${ }^{5}$.

As a result and because of inappropriate evidence, the purpose of this study was to investigate, by the single cell gel (comet) assay in vitro, whether sodium fluoride $(\mathrm{NaF})$ induces DNA breakage in Chinese hamster ovary (CHO) cells or not. We chose to study the genotoxicity of $\mathrm{CHO}$ cells because the mechanism of induced DNA damage in these cells is well documented. The results will contribute to a better understanding of the influence of $\mathrm{NaF}$ on genotoxicity to cellular system.

\section{MATERIALS AND METHODS Treatment of cells}

$\mathrm{CHO}$ cells were cultivated in suspension in F10 medium (Life Sciences, NY, USA) supplemented with $10 \%$ fetal calf serum (Life Technologies, NY, USA), $100 \mathrm{U} / \mathrm{ml}$ penicillin (Life Technologies, NY, USA) and $100 \mathrm{U} / \mathrm{ml}$ streptomycin (Life Technologies, NY, USA) at $37^{\circ} \mathrm{C}$ with $5 \% \mathrm{CO}_{2}$. Cells were seeded into each dish of multiwells (Corning, NY, USA, $10 \mathrm{~cm}$ in diameter) and cultured for 3 days prior to treatment with the test substance. At the beginning of the treatment, cells were trypsinized with $2 \mathrm{ml}(0.15 \%)$ of trypsine solution (Life Technologies, NY, USA). After 3 minutes, $2 \mathrm{ml}$ of the complete medium were added and the cells were centrifuged at $1,000 \mathrm{rpm}$ during 5 minutes and washed twice with fresh medium and resuspended with fresh medium. $1 \times 10^{4}$ cells $(\cong 10 \mu \mathrm{l})$ were used in each treatment. Ten microliters of $\mathrm{NaF}$ (Sigma, St. Louis, USA) were added to the suspension of $\mathrm{CHO}$ cells to achieve final concentrations ranging from $7-100 \mu \mathrm{g} / \mathrm{ml}$. These concentrations were defined in accordance with referenced publications ${ }^{1,24}$. The same volume was added to control cultures of either negative control (distilled water) or a reference alkylating agent MMS (methylmethasulfonate, Sigma Aldrich, St. Louis, USA) at a concentration of $1 \mu \mathrm{g} / \mathrm{ml}$ (positive control). Each individual substance was tested in at least three separate experiments for each individual treatment. After incubating the test tubes for $3 \mathrm{~h}$ at $37^{\circ} \mathrm{C}$, the cells were centrifuged at $1,000 \mathrm{rpm}$ (179.2 x g) during 5 minutes and washed twice with fresh medium and resuspended with fresh medium.

\section{Single cell gel (comet) assay}

The protocol used for single cell gel (comet) assay followed the guidelines proposed by Tice et al. ${ }^{23}$ (2000). Briefly, a volume of $10 \mu \mathrm{l}$ of cells were added to $120 \mu \mathrm{l}$ of $0.5 \%$ low-melting point agarose at $37^{\circ} \mathrm{C}$, layered onto a pre-coated slide with $1.5 \%$ regular agarose (Life Technologies, Auckland, New Zealand), and covered with a coverslip. After brief solidification of agarose in refrigerator, the coverslip was removed and slides immersed in lysis solution (2.5 M sodium chloride - Merck, Darmstadt, Germany, $100 \mathrm{mM}$ ethylenediaminetetracetic - EDTA - Merck, Darmstadt, Germany, $10 \mathrm{mM}$ Tris-Chloridric acid - $\mathrm{HCl}$ buffer, $\mathrm{pH} 10$ JT Baker, Mexico City, Mexico, 1\% sodium sarcosinate - Sigma, St. Louis, USA - with $1 \%$ Triton X-100 - Mallinckrodt, Kentuchy, USA - and 10\% dymethylsulfoxide - DMSO - Mallinckrodt, Kentuchy, USA) for about 1 hour. Prior to electrophoresis, slides were left in alkaline buffer $(0.3 \mathrm{mM}$ $\mathrm{NaOH}$ - Merck, Darmstadt, Germany - and $1 \mathrm{mM}$ EDTA - Merck, Darmstadt, Germany, $\mathrm{pH}>13$ ) for 20 minutes and electrophoresed for another 20 minutes, at $25 \mathrm{~V}(0.86 \mathrm{~V} / \mathrm{cm})$ and $300 \mathrm{~mA}$. After electrophoresis, the slides were neutralized in $0.4 \mathrm{M}$ Tris- $\mathrm{HCl}$ (Life Technologies, Auckland, New Zealand) ( $\mathrm{pH} 7.5$ ), fixed in absolute ethanol (Merck, Darmstadt, Germany) and stored at room temperature until blind analysis in a fluorescence microscope at $400 \mathrm{X}$ magnification. In order to minimize extraneous DNA damage from ambient ultraviolet radiation, all steps were performed with reduced illumination.

\section{DNA damage}

An automatized analysis system (Comet Assay 2.2 - Perceptive Instruments, Haverhill, UK) was used to determine DNA damage. Two parameters were estimated: tail moment (tail DNA/total DNA x center of gravity) and tail intensity (percentage of DNA in tail) from 50 cells per treatment ${ }^{8}$.

\section{Cytotoxicity assay}

Cytotoxicity assessment is an integral part of the single cell gel (comet) assay. Since cytotoxicity produces strand breaks that show up as increased DNA migration, it is recommended not to perform the single cell gel (comet) assay on samples with more than $30 \%$ cytotoxicity. Thus, cell viability test for $\mathrm{CHO}$ cells was performed using Tripan blue staining ${ }^{19}$ (Merck, Darmstadt, Germany) before 
Ribeiro DA, Scolastici C, Marques MEA, Salvadori DMF. Fluoride does not induce DNA breakage in Chinese hamster ovary cells in vitro. Braz Oral Res 2004;18(3):192-6.

TABLE 1 - Mean \pm standard deviation of DNA damage (tail moment and tail intensity) in Chinese hamster ovary cells exposed to $\mathrm{NaF}$.

\begin{tabular}{c|c|c}
\hline \hline \multirow{2}{*}{$\mathrm{NaF}(\mu \mathrm{g} / \mathrm{ml})$} & \multicolumn{2}{|c}{ DNA damage } \\
\cline { 2 - 3 } & Tail moment & Tail intensity $^{\mathrm{a}}$ \\
\hline $0^{1}$ & $0.27 \pm 0.16$ & $2.99 \pm 1.06$ \\
\hline 7 & $0.53 \pm 0.15$ & $2.97 \pm 0.47$ \\
\hline 28 & $0.33 \pm 0.20$ & $3.01 \pm 1.20$ \\
\hline 56 & $0.47 \pm 0.17$ & $2.94 \pm 1.84$ \\
\hline 100 & $0.52 \pm 0.12$ & $3.23 \pm 1.22$ \\
\hline Positive control $^{2}$ & $3.50 \pm 1.23^{*}$ & $22.59 \pm 6.48^{*}$ \\
\hline \hline
\end{tabular}

${ }^{a}$ Data of three independent repeats; * $\mathrm{p}<0.05 ;{ }^{1}$ distilled water; ${ }^{2}$ methylmethasulfonate $(1 \mu \mathrm{g} / \mathrm{ml})$.

the beginning of the treatment. Namely, a freshly prepared solution of $10 \mu 1$ Tripan blue $(0.05 \%)$ in distilled water was mixed to $10 \mu \mathrm{l}$ of each cellular suspension during 20 minutes, and then spread onto a microscope slide and covered with a coverslip. Non-viable cells were blue-stained. At least 200 cells were counted.

\section{Statistical methods}

Parameters in triplicate from the single cell gel (comet) assay for treated cells versus control cells were performed as recommended by Wiklund, Agurell $^{25}$ (2003). Namely, the migration data were transformed into root square and analyzed by oneway ANOVA using the software SPSS (version 1.0, SPSS Sigma Stat, Chicago, USA) for Windows. For statistic significance, $\mathrm{p}<0.05$ was considered.

\section{RESULTS}

The single cell gel (comet) assay was used to measure DNA damage in $\mathrm{CHO}$ cells in vitro. DNA strand breaks were represented by the mean tail moment and tail intensity for 50 comets/sample. As seen in Table $1, \mathrm{NaF}$ did not induce strand breaks in DNA in any of the concentrations tested. The mean cell viability for $\mathrm{CHO}$ cells was approximately 95\% (data not shown).

\section{DISCUSSION}

The aim of this study was to evaluate the $\mathrm{NaF}$-induced genotoxic damage in $\mathrm{CHO}$ cells in vitro. The investigation was conducted utilizing the single cell gel (comet) assay. We have postulated that cell cultures have advantages over animal experimentation since they afford highly defined culture conditions, thereby avoiding the complex homeostatic mechanisms that occur in vivo. It is important to notice that the alkaline version of the single cell gel (comet) assay used is sensitive for a wide variety of DNA lesions, such as DNA strand breaks, alkali-labile sites lesions including abasic sites and incomplete repair sites. These lesions were estimated by the software Comet Assay II through tail moment and tail intensity. Tail moment is a virtual measure calculated by the computerized image analysis system considering both the length of DNA migration in the comet tail and the tail intensity. This parameter is one of the major indices of induced DNA damage among the various parameters calculated using this method. Tail intensity was calculated considering the percentage of DNA in the tail of comets. According to the proposed in vitro single cell gel (comet) assay testing guideline $^{23}$, cells should be exposed for 3-6 h. Herein, cells were exposed to $\mathrm{NaF}$ for $3 \mathrm{~h}$. Considering that alkylating agents are expected to be the most potent and abundant DNA-damaging chemical found in our environment ${ }^{14}$, we used MMS for alkylation damage characterizing the positive control.

Fluoride is well known as a specific and effective caries prophylactic agent and its systemic or local application has therefore been recommended widely in the past decades. However, excessive concentrations may cause extensive damage to biological systems. It has been established that therapeutic exposure to xenobiotics may result in their covalent binding to DNA, which may lead to genetic damage and could be an initial event in the process of chemical carcinogenesis ${ }^{6} . \mathrm{NaF}$, the first and still-recommended fluoride compound used for fluoridation of drinking water, was able to induce morphological and neoplastic transformation of Syrian hamster embryo cells ${ }^{11,15}$, as well as to increase chromosomal aberrations in $\mathrm{CHO}$ cells ${ }^{1}$. Furthermore, studies have shown that although $\mathrm{NaF}$ is a non-oxidant ion, it caused oxidative stress indirectly leading to DNA breakage ${ }^{2,3}$. Our results clearly demonstrated that $\mathrm{NaF}$ could not contribute to the damage of DNA. We assumed that these negative results were obtained because fluoride is not capable of forming adducts on DNA bases or those that intercalate in DNA secondary structure. Our results are consistent with those of other studies ${ }^{12,13,17,24}$. An earlier study conducted by our group reported that NaF did not induce DNA damage in oral mucosa cells in vitro either ${ }^{21}$. On the other hand, studies conducted by some researchers have 
Ribeiro DA, Scolastici C, Marques MEA, Salvadori DMF. Fluoride does not induce DNA breakage in Chinese hamster ovary cells in vitro. Braz Oral Res 2004;18(3):192-6.

reported that $\mathrm{NaF}$ inhibits both protein and DNA synthesis in cultures of mammalian cells ${ }^{9}$. Probably, the inhibition of DNA synthesis is a secondary effect on DNA and therefore there is no apparent mechanism by which the reported genotoxic effects can be induced by a direct interaction of fluoride on DNA. It is important to stress that the single cell gel (comet) assay does not necessarily provide evidence on a mutagenic potential of substances. The ability of this assay for detecting DNA damage makes possible to determine if a compound has the potential to induce DNA breakage as strand breaks; however this condition may or may not lead to true mutations.

According to the proposed in vitro single cell gel (comet) assay testing guideline ${ }^{23}$, highly damaged DNA may suggest dead cells; the latter were excluded from the analysis, since they could reflect possible cytotoxicity. Thus, the single cell gel (comet) assay expert group recommends a concurrent assessment of cellular viability ${ }^{23}$. Our results indicated that $\mathrm{CHO}$ cells were tested for cytotoxic-

\section{REFERENCES}

1. Aardema MJ, Gibson DP, LeBoeuf RA. Sodium fluorideinduced chromosome aberrations in different stages of the cell cycle: a proposed mechanism. Mutat Res 1989;223: 191-203.

2. Anuradha CD, Kanno S, Hirano S. Fluoride induces apoptosis by caspase-3 activation in human leukemia HL-60 cells. Arch Toxicol 2000;74:226-30.

3. Anuradha CD, Kanno S, Hirano S. Oxidative damage to mitochondria is a preliminary step to caspase- 3 activation in fluoride-induced apoptosis in HL-60 cells. Free Radic Biol Med 2001;31:367-73.

4. Denbesten PK, Thariani H. Biological mechanisms of fluorosis and level and timing of systemic exposure to fluoride with respect to fluorosis. J Dent Res 1992;71:1238-43.

5. Faccioni F, Franceschetti P, Cerpelloni M, Fracasso ME. In vivo study on metal release from fixed orthodontic appliances and DNA damage in oral mucosa cells. Am J Orthod Dentofacial Orthop 2003;124:687-93.

6. Fairbairn DW, Olive PL, O'Neill KL. The comet assay: a comprehensive review. Mutat Res 1995;339:37-59.

7. Gerdes RA. The influence of atmospheric hydrogen fluoride on the frequency of sex-linked recessive lethals and sterility in Drosophila melanogaster. Fluoride 1971;4:25-9.

8. Hartmann A, Agurell E, Beevers C, Brendler-Schwaab $\mathrm{S}$, Burlinson B, Clay $\mathrm{P}$, et al. Recommendations for conducting the in vivo alkaline Comet assay. $4^{\text {th }}$ International Comet Assay Workshop. Mutagenesis 2003;18:45-51.

9. Holland RI. Fluoride inhibition of protein and DNA synthesis in cell in vitro. Acta Pharmacol Toxicol 1979;45: 96-101.

10. Inorganic fluorides used in drinking-water and dental preparations. IARC Monogr Eval Carcinog Risk Chem Hum 1982;27:237-303. ity by trypan blue exclusion, and constantly more than $95 \%$ of cells excluded trypan.

\section{CONCLUSION}

In summary, our results indicate that $\mathrm{NaF}$ did not induce DNA lesions in CHO cells in vitro. Since genotoxicity tests form an important part of cancer research and risk assessment of potential carcinogens, our study represents an important contribution to the correct evaluation of the potential health risk associated with agents usually used in dental practice.

\section{ACKNOWLEDGMENTS}

CNPq (National Council for Scientific and Technological Development) (grant number: 141501/2002-2) and TOXICAN (Center for Genotoxins and Carcinogens Evaluation) supported this study.

11. Jones CA, Callaham MF, Huberman E. Sodium fluoride promotes morphological transformation of Syrian hamster embryo cells. Carcinogenesis 1988;9:2279-84.

12. Khalil AM, Da'dara AA. The genotoxic and cytotoxic activities of inorganic fluoride in cultured rat bone marrow cells. Arch Environ Contam Toxicol 1994;26:60-3.

13. Kleinsasser NH, Weissacher $\mathrm{H}$, Wallner BC, Kastenbauer ER, Harreus UA. Cytotoxicity and genotoxicity of fluorides in human mucosa and lymphocytes. Laryngorhinootologie 2001;80:187-90.

14. Kuehl DW, Serrano J, Naumann S. Identification of potentially mutagenic contaminants in the aquatic environment by liquid chromatographic-thermospray mass spectrometric characterization of in vitro DNA adducts. J Chromatogr A 1994;684:1113-9.

15. Lasne C, Chouroulinkov I. Transforming activities of sodium fluoride in cultured Syrian hamster embryo and BALB/3T3 cells. Cell Biol Toxicol 1988;4:311-24.

16. Li YM, Dunipace AJ, Stookey GK. Genotoxic effects of fluoride: a controversial issue. Mutat Res 1988;195: 127-36.

17. Li YM, Heerema NA, Dunipace AJ, Stookey GK. Genotoxic effects of fluoride evaluated by sister-chromatid exchange. Mutat Res 1987;192:191-201.

18. Li YM, Zhang W, Noblitt TW, Dunipace AJ, Stookey GK. Genotoxic evaluation of chronic fluoride exposure: sister-chromatid exchange study. Mutat Res 1989;227: 159-65.

19. McKelvey-Martin VJ, Green MH, Schmezer P, PoolZobel BL, De Méo MP, Collins A. The single cell gel electrophoresis assay (comet assay): a European review. Mutat Res 1993;288:47-63. 
Ribeiro DA, Scolastici C, Marques MEA, Salvadori DMF. Fluoride does not induce DNA breakage in Chinese hamster ovary cells in vitro. Braz Oral Res 2004;18(3):192-6.

20. Monsour PA, Kruger BJ, Smid JR. Effects of a single intravenous dose of sodium fluoride on plasma electrolytes and metabolites in rats, rabbits and cockerels. J Dent Res 1985;64:1281-5.

21. Ribeiro DA, Salvadori DMF, Assis GF, Marques MEA. Does fluoride cause DNA damage? An in vitro evaluation using rats oral mucosa cells. Braz J Oral Sci 2003;2: 268-71.

22. Slamenova D, Gabelova A, Ruppova K. Cytotoxicity and genotoxicity testing of sodium fluoride on Chinese hamster V79 cells and human EUE cells. Mutat Res 1992;16:109-15.

23. Tice RR, Agurell E, Anderson D, Burlinson B, Hartmann A, Kobayashi $\mathrm{H}$, et al. Single cell gel/comet assay: guidelines for in vitro and in vivo genetic toxicology testing. Environ Mol Mutagen 2000;35:206-21.

24. Tong CC, McQueen CA, Brat S, Williams GM. The lack of genotoxicity of sodium fluoride in a battery of cellular tests. Cell Biol Toxicol 1988;4:173-86.

25. Wiklund SJ, Agurell E. Aspects of design and statistical analysis in the Comet assay. Mutagenesis 2003;18: 167-75.

26. World Health Organization. WHO advocates affordable fluoride toothpastes for the developing countries. 1994. Available from: URL: http://home.iae.nl/users/lightnet/ health/fluoride.htm.

Received for publication on Mar 01, 2004 Accepted for publication on May 20, 2004 